\title{
A Geothermal Energy Supported Gas-steam Cogeneration Unit as a Possible Replacement for the Old Part of a Municipal CHP Plant (TEKO)
}

\author{
L. Böszörményi, G. Böszörményi
}

The need for more intensive utilization of local renewable energy sources is indisputable. Under the current economic circumstances their competitiveness in comparison with fossil fuels is rather low, if we do not take into account environmental considerations. Integrating geothermal sources into combined heat and power production in a municipal CHP plant would be an excellent solution to this problem. This concept could lead to an innovative type of power plant - a gas-steam cycle based, geothermal energy supported cogeneration unit.

Keywords: geothermal energy, combined heat and power plant, heat pump, waste heat boiler, district heating network

\section{List of symbols}

CHP combined heating and power plant

GT gas turbine cycle

ST steam turbine

WHB waste heat boiler

C condenser

HE heat exchanger

HP heat pump

$m_{\text {FWH }}$ mass flow of secondary geothermal water used for heating feed water

$m_{\mathrm{DH}}$ mass flow of secondary geothermal water used for use in the DHN

$m_{\text {SCGH }}$ mass flow of the secondary carrier of geothermal heat

\section{Introduction}

Revolutionary structural changes will be needed as worldwide energy consumption increases with rising populations and higher living standards. In response to the higher impacts on the environment (especially the threat of climate change caused by the greenhouse effect) and decreasing reserves of fossil fuels, other sources will be needed. The utilization of renewable sources is expected to increase above all between 2010-2040. In this time period, the proportion of power supplied from renewable sources will probably rise from $5 \%$ to approximately $35 \%$. Around 2050 the proportion from non-renewable and renewable sources will be equal, and after 2060 the proportion of power from renewable sources will be about $40 \%$.

For Slovakia, which is extremely poor in fossil fuels, the prospect of such an evolution should provide strong motivation for more intensive utilization of sustainable energy sources, especially solar and geothermal energy. Their current usage (6\% and $2 \%$ ) is much lower than it could be. While solar energy is suitable for use in projects in the range of some $\mathrm{kW}$, due to its low concentration, the power output from geo- thermal projects is significantly higher, and can be used for major projects. The plan for the geothermal project in Košice is to utilize about $100 \mathrm{MW}$ heat output from 8 geothermal doublets. About $2500 \mathrm{TJ}$ of heat could be obtained in this way. This is undoubtedly one of the boldest intitiatives of its type in the world today.

\section{Feasibility of utilizing geothermal heat directly in the district heating network (DHN)}

The simple, direct use of geothermal heat in the District Heating Network (DHN) cannot be a feasible way of replacing the existing CHP plant under the current economic circumstances, due to its low efficiency. The main reason for this low efficiency is the conflict between geothermal heat and heat produced in cogeneration, which means that the heat produced by the cogeneration unit would be replaced by geothermal heat. Limiting the cogenerated heat production would cause a decrease in power production, which plays a key role in the efficiency of this unit. Therefore this alternative must be rejected.

The energy policy of the government, which supports the utilization of renewable sources, accepts the plan to establish of a cogeneration unit in 2004-2005 to replace a part of the CHP plant that is reaching the end of its working life. Cogeneration based on a gas-steam cycle is one of the most efficient ways of converting fossil fuels to other profitable energy forms, and for this reason it is one of the priorities in the energy policy. Its efficiency is based on longest possible utilization in the course of a year, as in the case of geothermal energy. Due to low demand for heating in the summer period, it is impossible to fulfil this condition.

The way to improve the efficiency of the geothermal project in Košice is by changing the basic philosophy. It is also important to reduce investment costs and to decrease the amount of geothermal heat used in a year. 


\section{Integrating the geothermal potential of the Košice basin into the combined heat and power production system in TEKO}

Motivated by a vision of supplying energy for Košice with a major proportion of clean and renewable energy, which could qualify for membership of the prestigeous "Energie-Cités - Association of European Municipalities for a Local Sustainable Energy Policy" network, the authors of this paper sought for a feasible concept, in which geothermal energy would be utilized in a system of combined heat and power production, rather than only direct utilization in the DHN. The combined heat and power production would not be limited but would be supported by geothermal heat. This solution would be advantageous for the two companies TEKO and GEOTERM, and also for the end users.

The initial results were published in a summarized form. The aim of these publications was to draw the attention of engineers and above of business people to the fact that the low efficiency of only direct utilization of geothermal energy in the DHN will not be compensated for by the increasing price of fossil fuels. Approximately $60 \%$ of the cost of geothermal heat is accounted for by energy costs, and the increasing cost of fossil fuels would influence all its components, so the desired effect would not be achieved. Moreover, the current rising price of electricity increases the advantages of cogeneration, but reduces the advantages of geothermal heating. For this reason, the use of hybrid CHP plants with the simultaneous use of fossil and geothermal sources was considered. This can be done using existing machinery, but a special design for the planned gas-steam cycle seems to be desirable. A gas-steam cycle based cogeneration unit with integrated support of geothermal energy could be implemented to supply the city with heat.

\section{The concept of a gas-steam cogeneration unit supported by geothermal energy}

There are many possible technical solutions of the gas-steam cogeneration source with integrated support of geothermal energy. In this concept geothermal heat is used mainly for heating the feed water in the steam cycle, so condensation production of electricity should be dominant in each proposal. The highest energy efficiency and the lowest environmental pollution can be achieved by the concept illustrated schematically in Fig. 1.

In this proposal the stream of secondary geothermal water $\dot{m}_{\text {SCGH }}$ will be divided into two parts in TEKO:

- $\dot{m}_{\mathrm{hfw}}$ for heating the feed water (condensate) in the heat exchanger of the steam cycle,

- $\dot{m}_{\mathrm{DH}}$ for direct utilization in DHN.

Because geothermal heat is more efficient for heating the feed water, the flow $\dot{m}_{\mathrm{hfw}}$ should be higher than $\dot{m}_{\mathrm{DH}}$. After mixing the returning flows that were cooled down to different degrees, the heat will be pumped from the resulting flow, using the heat pump HP for indirect utilization in DHN. The

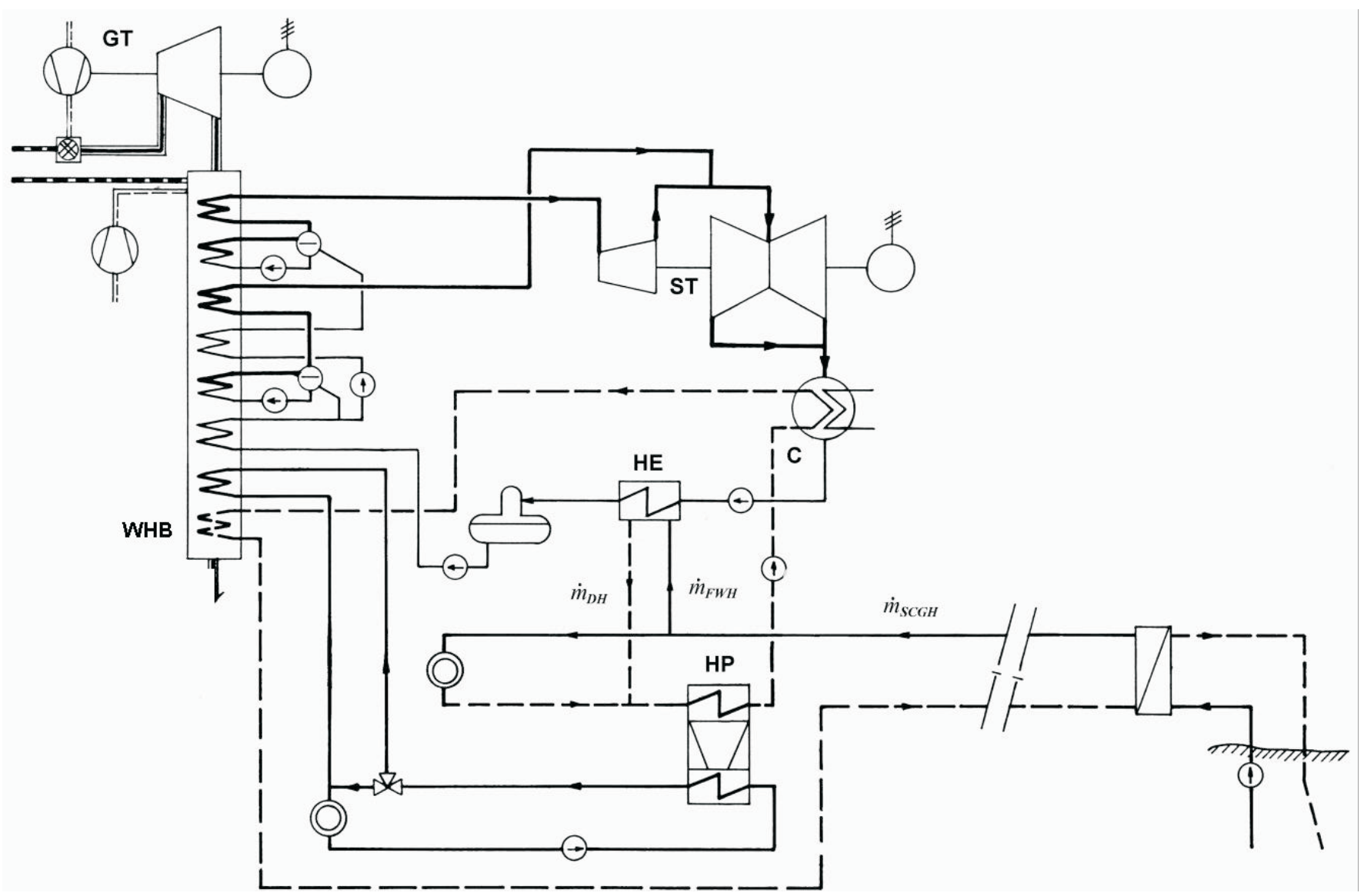

Fig. 1: Principal technological scheme of the gas-steam cogeneration unit with geothermal support 
heating water in the cycle of the heat pump's condenser can be overheated as required in the waste heat boiler WHB. In the evaporator of the heat pump the secondary geothermal water can be cooled down to such an extent that it can be used for cooling the condenser $\mathrm{C}$ of steam turbine ST. In condenser $\mathrm{C}$ the secondary geothermal water will be heated by 8 to $10 \mathrm{~K}$ by a part of the heat loss. Finally, in the waste heat boiler the secondary geothermal water can be heated by the heat losses from the outgoing flue gases at the same temperature, as is assumed in the case of only direct utilization in DHN. The flue gases can be cooled down in this way below the dew temperature and in addition to the sensible heat also the latent heat of the flue gases can branch away. After this, not only the pollution load but also the load by emission from exhaust emissions will be reduced, because the moisture will clean the outgoing flue gases. The heat losses of the waste heat boiler and condenser, which constitute a substantial part of the heat losses, will be accumulated through the geothermal water being reinjected into the earth's crust.

The parameters of the steam cycle will be adjusted to the processes analyzed above. The electric power of the steam turbine will also be determined mainly by the amount of condensate, and also indirectly by the stream of the secondary geothermal water used for heating the feed water. Taking into account the anticipated abundance of geothermal doublets, such a stream is expected, so at least two pressure levels of superheated steam must be dealt with.

There are other possible ways of designing the gas turbine, depending on the degree of overheating. In the extreme case of a gas-steam cycle without overheating, which is the most efficient variant, the power output of the gas cycle will be unnecessarily high, considering the current aims for the utilization of geothermal heat. For this reason it is important to turn our attention to overheating. The degree of overheating should be adjusted to the selected gas turbine. The ideal power output is when no additional air for combustion will need to be overheated.

It is important to pay attention to the concept of the waste heat boiler, which will be different from the standard double-pressure design, with (probably) high degree of overheating by the last heat exchanger, where the flue gases will be cooled to below dew point. The exiting of the flue gases into the atmosphere must also be adjusted to it.

The heat pump integrated into the combined heat and power production system, which pumps the heat from the returning secondary geothermal water into the CHP, plays a key role. If the parameters of the heat pump are chosen properly, its application will be effective, because the heating and cooling output would be used all year round. These parameters should therefore be chosen in such a way that the heat pump can supply the whole city with heat for domestic warm water production.

\section{Simplified analysis of winter period operation of a geothermal energy supported gas-steam cycle based cogeneration unit}

As shown in the scheme in Fig. 1., the operation of the gas-steam cycle based cogeneration source was analyzed to compare the effects of the possible ways of utilizing geothermal energy with the original, still officially supported idea, which involves direct feeding into DHN. The main parameters of the analysis were the following:

- Geothermal heat is distributed by secondary water to the TEKO from 6 doublets. If one doublet produces $60 \mathrm{~kg} / \mathrm{s}$ of mains water and the streams on the primary and secondary side of the heat exchangers of transmission line are equal, there is a total of $360 \mathrm{~kg} / \mathrm{s}$ of secondary geothermal water. The input temperature into the TEKO is approximately $120^{\circ} \mathrm{C}$.

- The stream of secondary mains water is divided in the ratio $2: 1$. This means that in the case of year-round operation $240 \mathrm{~kg} / \mathrm{s}$ water will be used for heating the feed water (from 4 doublets) and $120 \mathrm{~kg} / \mathrm{s}$ of water will be directly used in the DHN.

- Parameters of the high pressure steam

$\begin{array}{ll}\text { pressure: } & 10 \mathrm{MPa} \\ \text { temperature: } & 500^{\circ} \mathrm{C} \\ \text { stream: } & 160 \mathrm{~kg} / \mathrm{s}\end{array}$

- Parameters of the low pressure steam pressure: temperature:

$0,5 \mathrm{MPa}$ stream:

$300^{\circ} \mathrm{C}$

$80 \mathrm{~kg} / \mathrm{s}$

- Condensation pressure $0.004 \mathrm{MPa}$

- Parameters of the primary water in the DHN

$120^{\circ} \mathrm{C} / 50^{\circ} \mathrm{C}$

- Heat output of the heat pump

$45 \mathrm{MW}$

- Temperature of the secondary water at the output of the TEKO

$60^{\circ} \mathrm{C}$

These parameters indicate that it would be possible to obtain about $245 \mathrm{MW}$ electric power from the steam cycle and the total heat output of the source would be from 190 to 200 MW. The total electric power of the source would depend on the selected gas turbine and on the degree of overheating, which is relatively independent from the utilization of geothermal heat. It is in principle possible to imagine a variant in which the cycle of the steam turbine would operate in the interval of the basic load and the gas cycle would be used as a source for regulation of electric power.

This source would provide GEOTERM with $2500 \mathrm{TJ} /$ year from 6 doublets instead of 8, which means a saving on investment costs of about 14 mil. USD, and also lower distribution costs. These savings could be invested in TEKO. This variant seems more advantageous for TEKO, which would pay for about $2500 \mathrm{TJ} /$ year but would in fact be able to utilize $4000 \mathrm{TJ} /$ year as heat (this difference represents the heat losses leaving the condenser of the steam cycle and the waste heat boiler) and more than $1000 \mathrm{TJ} /$ year as cooling capacity. Moreover, the company would decrease its emissions, and reduce its impact on the environment. World Bank studies have

Table 1: Savings on investments by decreasing emissions

\begin{tabular}{|c|c|}
\hline Type of emission & Environmental profit USD/t \\
\hline $\mathrm{CO}_{2}$ & 48 \\
\hline $\mathrm{NO}_{\mathrm{x}}$ & 1100 \\
\hline $\mathrm{SO}_{\mathrm{x}}$ & 2200 \\
\hline
\end{tabular}


shown that the following savings can result from decreasing emissions and reducing environmental damage.

Taking these savings into account, it would even be advantageous for TEKO to buy the geothermal heat at a price higher than its selling price.

\section{Conclusions}

The concept of a geothermal energy supported gas-steam cycle based cogeneration unit appears very promising and our analysis shows that a new philosophy may lead to good results. The specification of the optimal variant of this concept and also the overall evaluation of its power supply, economic and environmental potential should form the subject of a very serious feasibility study.

The establishment and functioning of such a unique work would provide more power with fewer environmental impacts, contributing to the development of an efficient technology for converting fossil fuels to other energy forms, together with the use of geothermal sources. Optimized integration of the secondary geothermal heat carrier into the system of combined heat and power production in a gas-steam cycle based cogeneration unit and into the DHN could lead to very intensive utilization of its enthalpy, and also to a reduction in the consumption of primary energy. At the same time, huge heat losses or an accumulation of them in the earth's crust will be utilized, and the working life of the geothermal wells will be extended.

The realization of this project would be a success for the energy policy of Slovakia.

The main aim of the energy policy of the European Union is to increase the proportion of renewable energy source utilization from $6 \%$ to $12 \%$ in 2010 , and to reduce the emissions of greenhouse gases by $8 \%$ in comparison with 1990 . Slovakia has serious ambitions to join the EU, and will have to participate in this programme. If any version of the geothermal project is realized, it will form a major part of Slovakia's renewable clean energy programme. The interest of Slovak engineers in the new concept is surprisingly low, paradoxically lower than that of engineers in foreign countries. There has been no adequate response from the state authorities dealing with regional energy and environmental policy was presented. As a result of this neglect, no local funding has yet been made available for this work.

\section{References}

[1] Böszörményi, L.: Možnosti zlepšenia ekonomických ukazatel' ov košického geotermálneho projektu. Konferencia s medzinárodnou účastou „Podnikanie v energetike“. DT ZSVTS Košice, Košice 1998.

[2] Böszörményi, L.: Úvahy o využívani hydrogeotermálneho potenciálu Košickej kotliny pri kombinovanej výrobe tepla a elektriny. Časopis EE, 5, 1999, č. 6

[3] Böszörményi, L.: Geotermálna podpora kombinovanej výroby elektriny a tepla. Seminár Kogeneračné zdroje, DT ZSVTS Bratislava, Bratislava, 2000

[4] Böszörményi, L.: Optimierte Geothermienutzung bei der gekoppelten Strom- und Wärmeerzeugung in einer GuD-Anlage. International Conference World Sustainable Energy Day 2000, Wels/Austria, 2000

[5] Böszörményi, L.: Kraft-Wärme-Kälte-Kopplung mit geothermischer Unterstützung. VDI-Berichte 1594, VDI Verlag GmbH, Düsseldorf, 2001

[6] Geotermálna energia pre centrálne zásobovanie teplom v meste Košice. GEOTERM Košice, Košice, 1999

[7] Riešenie náhrady zastaralých zdrojov tepla v TEKO Košice. Výskumný ústav energetický EGÚ Bratislava, Bratislava, 1996

[8] VDI Nachrichten Magazin. Sonderbeilage zur EXPO 2000, VDI Verlag GmbH, Düsseldorf, 2000

Doc. Ing. Ladislav Böszörményi, CSc.

phone: 00421-95-6024241

fax.: 00421-95-6321558

e-mail: boszla@ccsun.tuke.sk

Department of Building Structures

Technical University of Košice

Faculty of Civil Engineering

Vysokoškolská 4, 04201 Košice, Slovak Republic

Ing. Gabriel Böszörményi

e-mail: G.Boszormenyi@sh.cvut.cz

Department of Fluid Dynamics and Power EngineeringDivision of Compressors, Refrigeration

and Hydraulic Machines

Czech Technical University in Prague

Faculty of Mechanical Engineering

Technická 4, 16607 Praha 6, Czech Republic 